\title{
The Expenditure Impacts of London's Higher Education Institutions: The Role of Diverse Income Sources
}

December, 2013

\author{
Kristinn Hermannsson ${ }^{\ddagger}$ \\ Katerina Lisenkova* \\ Peter G McGregor ${ }^{\dagger}$ \\ and \\ $\mathrm{J} \mathrm{Kim} \mathrm{Swales}^{\dagger}$
}

${ }^{\ddagger}$ School of Education, University of Glasgow, St Andrews Building,

11 Eldon Street, Glasgow G3 6NH, United Kingdom.

Email: kristinn.hermannsson@glasgow.ac.uk

\author{
${ }^{\dagger}$ Fraser of Allander Institute, Department of Economics, University of \\ Strathclyde, Sir William Duncan Building, 130 Rottenrow, Glasgow G4 0GE, \\ United Kingdom. Emails: p.mcgregor@strath.ac.uk, j.k.swales@strath.ac.uk \\ *National Institute of Economic and Social Research (NIESR), 2 Dean Trench \\ Street, Smith Square, London, SW1P 3HE, United Kingdom. \\ Email: k.lisenkova@niesr.ac.uk
}

\begin{abstract}
Acknowledgements:
This paper is an output of the Overall Impact of Higher Education Institutions on Regional Economies project, funded by the Economic and Social Research Council (ESRC), Scottish Funding Council (SFC), the Higher Education Funding Council of England (HEFCE), the Higher Education Funding Council of Wales (HEFCW) and the Department for Employment and Learning Northern Ireland (DELNI) - RES-171-25-0032. We also acknowledge additional funding from the Centre for Public Policy for Regions. We are indebted to Ursula Kelly for helpful discussions and advice. The project was one of nine funded through the Impact of Higher Education Institutions on Regional Economies Initiative.
\end{abstract}




\begin{abstract}
This paper analyses the impact of London-based Higher Education Institutions (HEIs) on the English economy. When we treat each of the HEIs as separate sectors in conventional input-output analysis, their expenditure impacts appear rather homogenous, with the apparent heterogeneity of their overall impacts being primarily driven by scale. However, a disaggregation of income by source reveals considerable variation in their dependence upon public funding and ability to draw in income/funding from external sources. Acknowledging the possible alternative uses of the public funding and deriving balanced expenditure multipliers reveals large differences in the net-expenditure impact with the source of variation being the origin of income. The institutional multiplier is driven by the ability to attract external funding, which would typically favour research intensive institutions. However, the impacts of students' consumption expenditures are also significant. In terms of ranking of multipliers the overall results are mixed.
\end{abstract}

Keywords: London, Higher Education Institutions, Input-Output, England, Impact study, Multipliers, budget constraint.

JEL classifications: R51, R15, H75, I23. 


\section{Introduction}

Higher Education Institutions (HEIs) are diverse in terms of their scale and nature. Some are research intensive with relatively few students, whereas other are more student driven. Incomes are equally diverse, with institutions drawing on sources such as the funding council, tuition fees, domestic and foreign research funding, commercial research contracts and charities. This paper explores how these characteristics affect the regional expenditure impacts of individual HEIs.

We apply our analysis to London, which is a particularly rich case. It is the largest centre of higher education in the UK, with just under 290,000 FTE students attending 39 diverse institutions. Everything from small art institutions such as Rose Bruford College or the Courthauld Institute of Art to large research universities such as UCL. This is in addition to highly specialised research institutes such as the Institute of Cancer Research. Furthermore it hosts student-intensive institutions serving the local economy like Thames Valley University and specialised institutions charging high fees to an international student body such as the London Business school. This extraordinary diversity makes it particularly interesting to study the impacts of all London HEIs within a single unified framework.

In order to address this we construct a unique economic database where we draw on accounting data to identify each London HEI as a separate sector in an Input-Output (IO) table, allowing for heterogeneity of income sources. We then adopt an IO accounting approach and undertake various attribution analyses. 
We acknowledge the importance of variation in the sources of revenues to HEIs, reflecting, in particular, the dependence of these HEIs on public funding. We acknowledge that different types of students drive different expenditure impacts. Furthermore, we recognise the public funding of HEI students also has an opportunity cost. Again considerable heterogeneity is revealed across HEIs when we accommodate this.

There have been numerous studies of the impact of higher education institutions (HEIs) on their host regional economies that focus solely on their effect on the local demand for goods and services (see e.g. Drucker \& Goldstein 2007, Florax, 1992, McGregor et al., 2006 and Sigfried et al 2007 for reviews). These demand-side studies treat a university like any other business which demands goods and factor services within the region. Similarly, students are treated analogously to tourists, as a source of consumption spending for the local economy.

Apart from academic work on the expenditure impacts of HEIs and their students there are countless studies published by advocacy groups and individual instituions that aim to demonstrate the HEIs economic impact ${ }^{1}$. These have come under criticsm for relaxing methodological rigour in favour of inflating the perceived economic impact (Sigfried et al, 2007). Hermannsson et al (2013a) point out that in a UK context the validity of expenditure impact studies has been doubted based on the notion that binding public budget

\footnotetext{
${ }^{1}$ Typically the most prominent focus is on the HEIs expenditure impacts, but other channels are also considered. For a summary of the arguments most frequently made see Drucker \& Goldstein (2007).
} 
constraints imply that the impact of HEIs expenditures is negligible. We acknowledge the potential importance of this constraint but conduct an analysis that seeks to quantify its importance.We show that, taking account of public funding acts to moderate estimated expenditure impacts, rather than to eliminate them altogether.

For many stakeholders expenditure impacts are very important, as is witnessed by the range of available impact studies. Expenditure impacts are felt without much lag and for some communities the local university is an important source of final demand injection. As we shall see, treated simply as businesses, the London HEIs support a non-negligable share of output in the English economy. However, it must be stressed that expenditure impacts are only part of a broader interaction between HEIs, the economy and the wider community. Importantly, HEIs stimulate the supply side of their host regional economies through activities such as: improving the skills in the labour force (Blundell et al., 2005; Bradley and Taylor 1996; Checchi, 2006; Harmon and Walker, 2003; Psacharopoulos and Patrinos 2004), undertaking knowledge exchange (Acs, 2009; Anselin et al., 1997; Fischer and Varga 2003; Parker and Zilberman 1993; Varga and Schalk 2004) and contributing to innovation (Andersson et al., 2009; Anselin et al., 2000; Jaffe 1989; Lundvall 2008). Recent evidence suggests human capital plays a key role in the causal link from HEIs to innovation (Faggian and McCann, 2009; Faggian et al., 2010). Furthermore, a persuasive case has been made that a more educated population results in long term indirect benefits, such as improved public health and lower crime rates (McMahon, 2004, 2009). Supply side-impacts are potentially large relative to 
demand-side impacts (Hermannsson et al., forthcoming) and merit a systematic study. However, that does not mean expenditure impacts are yet fully understood. This paper seeks to highlight some of those demand-side issues for London HEIs.

The rest of the paper is structured as follows. In Section 2 we provide a brief overview of the London higher education system and present key characteristics of individual London HEIs - including their funding sources and the level of funding relative to the number of staff and students. In Section 3 we outline the HEI-disaggregated IO accounting approach, and present the results of applying it to HEIs' own expenditures. While total institutional expenditure impacts vary considerably across HEIs, we show that this largely reflects differences in the scale of HEIs. Once we control for scale, by focussing on the value of individual HEI multipliers, the results exhibit a striking degree of homogeneity given the variety, and often highly specialised nature, of HEIs in London. We then show the impact of recognising alternative uses of the public funding of HEIs in Section 4. The resultant balanced expenditure HEI multipliers exhibit considerable heterogeneity. We discuss the overall impacts of HEIs by incorporating the effects of student expenditures in Section 5. One key finding is that a focus on overall expenditure impacts gives a misleading impression of a homogenous HEI sector in London, which is in fact characterised by considerable heterogeneity once differences in funding sources are recognised. We present brief conclusions in Section 6. 


\section{Key characteristics of London HEIs}

In the year 2006, which is the period to which our database applies, there were 39 Higher Education Institutions in London. In this study we exclude the Royal College of Nursing as data on its expenditures are not comparable with those of other institutions in the Higher Education Statistics Agency (HESA) dataset ${ }^{2}$. In column one of Table 1 the remaining 38 institutions are listed alphabetically by their official names. The second column gives convenient abbreviations of these names, which are used for the remainder of the paper. Also included in the table is a selection of the HEIs' more important characteristics, from the point of view of this impact study. Before analysing the data, a brief description of how the dataset was constructed is in order ${ }^{3}$.

Our starting point is a UK Input-Output table, which we use to derive an InputOutput table for England. An IO table is a matrix that identifies the sales and purchases of each production sector in a given economy in a consistent and complete way. We begin by augmenting this table by disaggregating the education sector. We first separately identify the non-HEI elements and then use data on the income and expenditures of London HEIs to create a separate sector for each institution. The table therefore details the expenditure pattern and composition of income for each London HEI in a consistent way.

\footnotetext{
2 This is unfortunate but should not change the overall analysis as the RCN is very small. It has 214 students or $0.07 \%$ of the London student population, but is slightly larger in terms of income - receiving approximately $0.19 \%$ of the income of the overall sector in London.

${ }^{3}$ This follows mutatis mutandis an approach originally developed for application in Scotland based on HESA data. For details see: Hermannsson et al (2010a).
} 
HESA (2007) provides details of the incomes of each HEI. In this analysis we separately identify the public funding ${ }^{4}$ of London HEIs and explore the impact of the alternative use of these funds. In particular, public funding of HEIs in London could be used alternatively to expand general public expenditure in England. Most HEIs draw a large share of their income from research and teaching grants from the Higher Education Funding Council England (HEFCE). This represents over four fifths of what we identify as public sector income. Other important income sources are: the tuition of fee-paying students; research grants funded by the private sector or non-profit organisations; public sector research grants obtained through competitive bidding at the UK-level or overseas, which are classified as interregional exports in this case; and other income sources such as payments for residence and catering services and various services rendered to local production sectors.

\footnotetext{
${ }^{4}$ We treat London as if it were a devolved region and therefore public funding refers to income sources, which are provided by the regional assemblies in N-Ireland, Scotland and Wales. Broadly this means HEFCE grants are treated as public funding, whereas income from the research councils is not subjected to this budget constraint (for details see: Hermannsson et al 2010b).
} 
Table 1 Key characteristics of London HEIs

\begin{tabular}{|c|c|c|c|c|c|c|c|}
\hline \multicolumn{2}{|l|}{ Institutions } & \multicolumn{2}{|c|}{ Income } & \multicolumn{2}{|c|}{ Employment } & \multicolumn{2}{|c|}{ Students } \\
\hline Formal name & $\begin{array}{l}\text { Abbreviated } \\
\text { name } \\
\text { (used in the } \\
\text { remainder of } \\
\text { this paper) }\end{array}$ & $\begin{array}{c}\text { Total } \\
\text { (f } \\
\text { million) }\end{array}$ & $\begin{array}{l}\text { Percentage } \\
\text { from public } \\
\text { funding }\end{array}$ & $\begin{array}{c}\text { Total } \\
\text { income } \\
\text { per FTE } \\
\text { employee } \\
\text { (f) }\end{array}$ & $\begin{array}{c}\text { Share of } \\
\text { wages in } \\
\text { expenditure }\end{array}$ & $\begin{array}{l}\text { Total final } \\
\text { demand } \\
\text { per FTE } \\
\text { student (f) }\end{array}$ & $\begin{array}{l}\text { Share } \\
\text { non- } \\
\text { English }\end{array}$ \\
\hline Birkbeck College & Birkbeck & 65 & $54 \%$ & 67,391 & $66 \%$ & 8,692 & $7 \%$ \\
\hline Brunel University & Brunel & 118 & $50 \%$ & 61,804 & $62 \%$ & 9,479 & $20 \%$ \\
\hline The Institute of Cancer Research & ICR & 63 & $28 \%$ & 79,869 & $61 \%$ & 359,548 & $40 \%$ \\
\hline Central School of Speech and Drama & CSoSD & 10 & $62 \%$ & 113,212 & $48 \%$ & 11,771 & $17 \%$ \\
\hline City University & City & 136 & $24 \%$ & 79,482 & $59 \%$ & 10,350 & $28 \%$ \\
\hline Conservatoire for Dance and Drama & $C D \& D$ & 12 & $81 \%$ & 43,840 & $58 \%$ & 11,690 & $34 \%$ \\
\hline Courtauld Institute of Art & Courtauld & 10 & $27 \%$ & 90,595 & $52 \%$ & 26,640 & $39 \%$ \\
\hline The University of East London & East London & 94 & $56 \%$ & 76,465 & $52 \%$ & 7,358 & $18 \%$ \\
\hline Goldsmiths College & Goldsmiths & 59 & $58 \%$ & 74,121 & $62 \%$ & 9,539 & $22 \%$ \\
\hline The University of Greenwich & Greenwich & 134 & $52 \%$ & 83,381 & $47 \%$ & 7,946 & $21 \%$ \\
\hline $\begin{array}{l}\text { Imperial College of Science, } \\
\text { Technology \& Medicine }\end{array}$ & Imperial & 525 & $35 \%$ & 90,091 & $56 \%$ & 43,652 & $41 \%$ \\
\hline Institute of Education & IoE & 64 & $47 \%$ & 86,464 & $51 \%$ & 21,320 & $21 \%$ \\
\hline King's College London & King's College & 404 & $44 \%$ & 87,880 & $61 \%$ & 23,569 & $22 \%$ \\
\hline Kingston University & Kingston & 132 & $55 \%$ & 79,244 & $59 \%$ & 7,207 & $16 \%$ \\
\hline University of the Arts, London & University of the Arts & 143 & $55 \%$ & 70,238 & $55 \%$ & 11,449 & $36 \%$ \\
\hline London Business School & LBS & 87 & $10 \%$ & 134,771 & $46 \%$ & 54,483 & $69 \%$ \\
\hline London Metropolitan University & Metropolitan & 151 & $58 \%$ & 69,201 & $66 \%$ & 7,089 & $26 \%$ \\
\hline London South Bank University & South Bank & 113 & $42 \%$ & 74,897 & $59 \%$ & 7,605 & $17 \%$ \\
\hline $\begin{array}{l}\text { London School of Economics } \\
\text { and Political Science }\end{array}$ & LSE & 156 & $22 \%$ & 86,407 & $52 \%$ & 19,745 & $67 \%$ \\
\hline $\begin{array}{l}\text { London School of Hygiene } \\
\text { and Tropical Medicine }\end{array}$ & LSHTM & 66 & $29 \%$ & 93,084 & $51 \%$ & 73,846 & $57 \%$ \\
\hline Middlesex University & Middlesex & 131 & $48 \%$ & 77,326 & $55 \%$ & 6,182 & $24 \%$ \\
\hline Queen Mary and Westfield College & Queen Mary & 200 & $45 \%$ & 72,782 & $60 \%$ & 19,006 & $25 \%$ \\
\hline $\begin{array}{l}\text { Ravensbourne College of Design } \\
\text { and Communication }\end{array}$ & Ravensbourne & 11 & $74 \%$ & 76,206 & $51 \%$ & 9,495 & $16 \%$ \\
\hline Roehampton University & Roehampton & 47 & $65 \%$ & 49,820 & $66 \%$ & 6,180 & $12 \%$ \\
\hline Rose Bruford College & Rose Bruford & 6 & $75 \%$ & 68,879 & $46 \%$ & 8,515 & $22 \%$ \\
\hline Royal Academy of Music & RAM & 15 & $34 \%$ & 80,225 & $55 \%$ & 21,012 & $50 \%$ \\
\hline Royal College of Art & RCA & 25 & $60 \%$ & 89,455 & $44 \%$ & 29,834 & $45 \%$ \\
\hline Royal College of Music & $\mathrm{RCM}$ & 14 & $38 \%$ & 92,300 & $54 \%$ & 22,097 & $50 \%$ \\
\hline Royal Holloway and Bedford New College & Royal Holloway & 92 & $45 \%$ & 71,640 & $58 \%$ & 13,247 & $31 \%$ \\
\hline The Royal Veterinary College & RVC & 46 & $51 \%$ & 81,012 & $55 \%$ & 31,445 & $19 \%$ \\
\hline St George's Hospital Medical School & St George's & 71 & $50 \%$ & 85,323 & $66 \%$ & 28,278 & $11 \%$ \\
\hline St Mary's College & St Mary's & 22 & $72 \%$ & 58,553 & $63 \%$ & 6,688 & $13 \%$ \\
\hline The School of Oriental and African Studies & SoOA & 47 & $35 \%$ & 66,155 & $62 \%$ & 12,417 & $47 \%$ \\
\hline The School of Pharmacy & SoPh & 18 & $45 \%$ & 80,997 & $55 \%$ & 18,970 & $23 \%$ \\
\hline Thames Valley University & Thames Valley & 103 & $54 \%$ & 53,535 & $69 \%$ & 8,459 & $17 \%$ \\
\hline Trinity Laban & Trinity Laban & 15 & $50 \%$ & 59,462 & $59 \%$ & 19,339 & $36 \%$ \\
\hline University College London & UCL & 585 & $36 \%$ & 82,782 & $61 \%$ & 34,206 & $32 \%$ \\
\hline The University of Westminster & Westminster & 138 & $55 \%$ & 75,935 & $56 \%$ & 8,468 & $22 \%$ \\
\hline & Total/average & 4,130 & $43 \%$ & 78,647 & $58 \%$ & 14,259 & $25 \%$ \\
\hline
\end{tabular}


Adjustments had to me made to reflect the particulars of the institutional structure. The University of London is a federal institution, with central functions listed as a separate institution in HESA accounts. The centre's incomes and expenditures were distributed among the member colleges pro rata in line with their income as revealed in HESA data. The Conservatoire of Dance and Drama is a network institution, which distributes income to partner colleges (which do not report to HESA). Therefore its expenditures in the HESA accounts do not reflect the actual expenditure structure of the entire institution. To correct for this we impose the average wage/expenditure ratio as revealed by other London HEIs.

Column three shows the total income for the Higher Education sector in London in 2006 and how this was distributed among the individual institutions. Of the total income of $£ 4,130$ million, nearly $14.2 \%$ goes to the largest, UCL, $12.7 \%$ to Imperial and $9.8 \%$ to King's College. The largest institution is over 98 times the size of the smallest, Rose Bruford. This large variation in the size of individual institutions suggests that there is likely to be heterogeneity in other aspects of their operation. The rest of the information in the table is standardised against the institution's income, number of staff or student population.

Column four gives the proportion of the total funding for each London HEI that comes from the government funding channelled through HEFCE and other sources. Note that, while HEIs are heavily funded by the government, they are non-profit organisations and are not formally part of the public sector. On 
average $43 \%$ of London HEIs' funding comes from this source. However, the variation around the $43 \%$ figure is as important for the present paper. There is a considerable range: LBS is an outlier, which receives only $10 \%$ of its total funding from public sources, LSE 22\% and City 24\%. Conservatoire for Dance and Drama has maximum dependence on public funding among London HEIs, at $81 \%$, with Rose Bruford, Ravensbourne, and St Mary's on 75\%, 74\% and $72 \%$ respectively.

Column five presents the income per member of staff. In 2006 the total employment in London HEIs was 52.5 thousand, so that the income per member of staff averages at £78.6 thousand. The ranking of London HEIs by employment is very close to that by income, but there is some variation and this is reflected in variation in income per staff member across institutions. The institutions have values that range between the high of $£ 134,771$ thousand for LBS to $£ 49.8$ for Roehampton (if we ignore CD\&D).

However, variation in the share of wages in total income presented in column six is more limited. The average figure for the sector as a whole is $58 \%$, with a range from RCA on $44 \%$ to Thames on $69 \%$. It is clear that across all London institutions wage payments make up a significant and relatively similar share of total HEI expenditure.

University income per student is given in column seven of Table 1 . It is important to note that this is the total income of the institution divided by the total number of students, measured in FTEs. For the London HEI sector as a 
whole, the average was $£ 14.3$ thousand. However, even if we omit the Institute of Cancer Research, which is an outlier, there is a high degree of variation across institutions from $£ 73.8$ thousand for London School of Hygiene and Tropical Medicine to $£ 6.2$ thousand for Roehampton and Middlesex.

Finally, column eight presents figures for the proportion of students that are non-English. On average $25 \%$ of all students in London HEIs come from outwith England. Again there are large differences across institutions. Birkbeck is an outlier, taking 93\% of its students from England, whilst LBS and LSE take only $31 \%$ and $33 \%$ of their students from their home region.

The information given in Table 1 reflects the fact that HEIs actually perform a range of activities, covering teaching, research and knowledge exchange that can be funded in a variety of ways. There are systematic differences in the way in which different London HEIs operate and the weighting of the activities that they undertake. This is especially the case for the smaller and more specialised HEIs, but is also apparent amongst the more conventional London universities. We would expect this variation in activities to affect the expenditure impacts of individual London HEIs on the English economy. It is this proposition that we test in the remainder of the paper.

\section{HEI expenditure impacts and conventional IO impact analysis}

Regional impact analyses are frequently used to capture the total spending effects of institutions, projects or events. These analyses include multiplier, or 
“knock-on”, impacts of any expenditure injection, obtained by summing up subsequent internal feedbacks within the economy. For the the regional economic impact of HEI expenditure Florax (1992) identified over 40 studies of and much has been published since. McGregor et al (2006) summarise the methods and findings of the main UK studies. Most of these studies, especially earlier ones, are based on Keynesian income-expenditure models (Brownrigg, 1973; Bleaney et al, 1992; Armstrong, 1993; Battu et al., 1998) whilst a smaller number use straightforward or extended IO modelling (Blake and McDowell, 1967; Harris, 1997; Kelly et al, 2004; Hermannsson et al., 2013ab). We use IO as an accounting framework that we modify to acknowledge the possible alternative use of public funding within England.

The direct spending impact of universities is separated into two categories: the impacts of HEIs' own expenditures on intermediate inputs (including the wages of their own staff) and the consumption expenditures of their students. We begin with a brief account of conventional IO impact analysis (for a review see e.g.: Armstrong \& Taylor 2000, Loveridge 2004, Miller \& Blair 2009) and then apply this analysis to London HEI and their students.

Regional demand-driven models, including IO, distinguish between two types of expenditures: exogenous and endogenous. Exogenous expenditures are independent of the level of economic activity within the host economy. In IO studies exports, government expenditure and investment are typically taken to be exogenous. On the other hand, endogenous expenditures are driven by the overall level of economic activity within the host economy. Specifically, 
demand for intermediate inputs and sometimes household consumption demands are taken to be endogenous. Input-output tables contain information about sales and purchases between different sectors and actors within the economy. Based on the notion that exogenous expenditure determines endogenous activity, multipliers can be derived. The output multiplier for each sector is the change in total output for the economy as a whole resulting from a unit change in the final demand for that sector. This allows a convenient expression for the gross output $q_{\mathrm{i}}$ attributable to the exogenous expenditures (or final demands) $f_{i}$ on the output of sector i:

$$
q_{i}=m_{i} f_{i}
$$

where $m_{i}$ is the output multiplier for sector $i$.

Multipliers can be derived for a variety of activity outcomes, including employment, income, output or GDP. The Type-II multipliers reported in this paper are those conventionally reported in demand-driven IO impact studies. Type-II multipliers incorporate not only the increase in demand for intermediate inputs but also induced household consumption effects, generated by changes in wage income, as endogenous elements in the multiplier process. For further details see Miller and Blair (2009, Ch. 6). 
The IO table provides a useful accounting framework in which each HEI can be attributed with the total regional economic activity driven by its final demand ${ }^{6}$. This impact effect is composed of both the final demand for the HEI's output and also the knock-on impacts on other sectors, generated through directly and indirectly linked intermediate demand and household consumption. One key strength of IO as an accounting framework is that it is consistent. When such an attribution exercise is carried out on a sector-by-sector basis, the sum of the impacts attributable to each sector's final demands equals the economy-wide total.

\section{Results of the conventional IO analysis applied to HEIs' own expenditures}

Table 2 and Figure 1 summarise conventional Type II IO-based impact estimates for London HEIs. These are obtained by applying equation 1 to each HEI treated as a separate sector in our HEI-disaggregated IO table. ${ }^{7}$ The first column shows the income of each HEI in London in 2006, as in Table 1. Columns two, three and four give the total direct, indirect and induced (Type-

\footnotetext{
${ }^{6}$ Demand-driven models are based on some restrictive assumptions, in particular a passive supply side. Although these can be motivated under condition of excess capacity or long run factor mobility (McGregor et al, 1996) we do not believe that the economy of England (or London) can be accurately characterised by an entirely passive supply side, even over the longer-term. However, we regard the results as simply reflecting an accounting attribution. This is appropriate as we are not considering the impact of changes at the margin but attributing endogenous impacts to exogenous expenditures based on historical economic accounts.

${ }^{7}$ For each institution, the direct, indirect and induced effects are calculated using the final demand for their output of the particular institution. This is not the total income of the institution (which will incorporate some sales to local intermediate and household consumption demands).
} 
II) impact of HEI spending on total English output, GDP and FTE employment respectively.

The first point to note is that the expenditures of London HEIs, considered as a single production sector, have a major impact on: English gross output $£ 10,617$ million, $0.87 \%$ of the English total; GDP £5,691, 0.53\%, and employment, $98,340,0.55 \%$. 
Table 2. Conventional Type-II impacts of London HEIs in 2006 (final demand plus multiplier effects).

\begin{tabular}{|c|c|c|c|c|}
\hline & Income & Output $\mathbf{f m}$ & GDP $\mathbf{f m}$ & $\begin{array}{l}\text { Employment } \\
\text { FTEs (000's) }\end{array}$ \\
\hline Birkbeck & 65 & 167 & 94 & 1,698 \\
\hline Brunel & 118 & 313 & 172 & 3,246 \\
\hline ICR & 63 & 143 & 78 & 1,303 \\
\hline CSoSD & 10 & 27 & 13 & 336 \\
\hline City & 136 & 300 & 161 & 2,719 \\
\hline$C D \& D$ & 12 & 36 & 19 & 447 \\
\hline Courtauld & 10 & 28 & 14 & 244 \\
\hline East London & 94 & 247 & 127 & 2,276 \\
\hline Goldsmiths & 59 & 159 & 88 & 1,570 \\
\hline Greenwich & 134 & 347 & 172 & 3,037 \\
\hline Imperial & 525 & 1,403 & 742 & 12,200 \\
\hline IoE & 64 & 165 & 85 & 1,462 \\
\hline King's College & 404 & 1,030 & 561 & 9,023 \\
\hline Kingston & 132 & 331 & 178 & 3,046 \\
\hline University of the Arts & 143 & 385 & 202 & 3,878 \\
\hline LBS & 87 & 179 & 88 & 1,329 \\
\hline Metropolitan & 151 & 400 & 225 & 4,096 \\
\hline South Bank & 113 & 263 & 142 & 2,451 \\
\hline LSE & 156 & 412 & 212 & 3,650 \\
\hline LSHTM & 66 & 174 & 89 & 1,487 \\
\hline Middlesex & 131 & 336 & 176 & 3,224 \\
\hline Queen Mary & 200 & 528 & 286 & 5,059 \\
\hline Ravensbourne & 11 & 33 & 17 & 308 \\
\hline Roehampton & 47 & 120 & 68 & 1,381 \\
\hline Rose Bruford & 6 & 17 & 8 & 162 \\
\hline RAM & 15 & 37 & 19 & 341 \\
\hline RCA & 25 & 65 & 32 & 565 \\
\hline $\mathrm{RCM}$ & 14 & 33 & 17 & 282 \\
\hline Royal Holloway & 92 & 248 & 133 & 2,382 \\
\hline RVC & 46 & 129 & 68 & 1,166 \\
\hline St George's & 71 & 175 & 99 & 1,557 \\
\hline St Mary's & 22 & 58 & 32 & 635 \\
\hline SoOA & 47 & 124 & 68 & 1,243 \\
\hline SoPh & 18 & 47 & 24 & 421 \\
\hline Thames Valley & 103 & 239 & 137 & 2,646 \\
\hline Trinity Laban & 15 & 35 & 19 & 366 \\
\hline UCL & 585 & 1,528 & 836 & 13,727 \\
\hline Westminster & 138 & 359 & 190 & 3,378 \\
\hline Total & 4,130 & 10,617 & 5,691 & 98,340 \\
\hline $\begin{array}{l}\% \text { of ENG total } \\
\text { output/GDP/employment }\end{array}$ & & $0.87 \%$ & $0.53 \%$ & $0.55 \%$ \\
\hline
\end{tabular}

The second point is that there is considerable variation in the impacts of individual HEIs, as simple inspection of Figure 1 makes clear. However, these are clearly strongly affected by the initial scale of the individual institutions. A natural way of eliminating scale effects in an IO impact analysis is to focus on the multiplier values associated with 
a unit change in the final demands for each HEI's output. These multiplier values $\left(\mathrm{m}_{\mathrm{i}}\right.$ in equation 2) are shown in Figure 2 for each of the 38 HEIs.

Figure 1 Output impact (Type-II) of London HEIs expenditures, Em

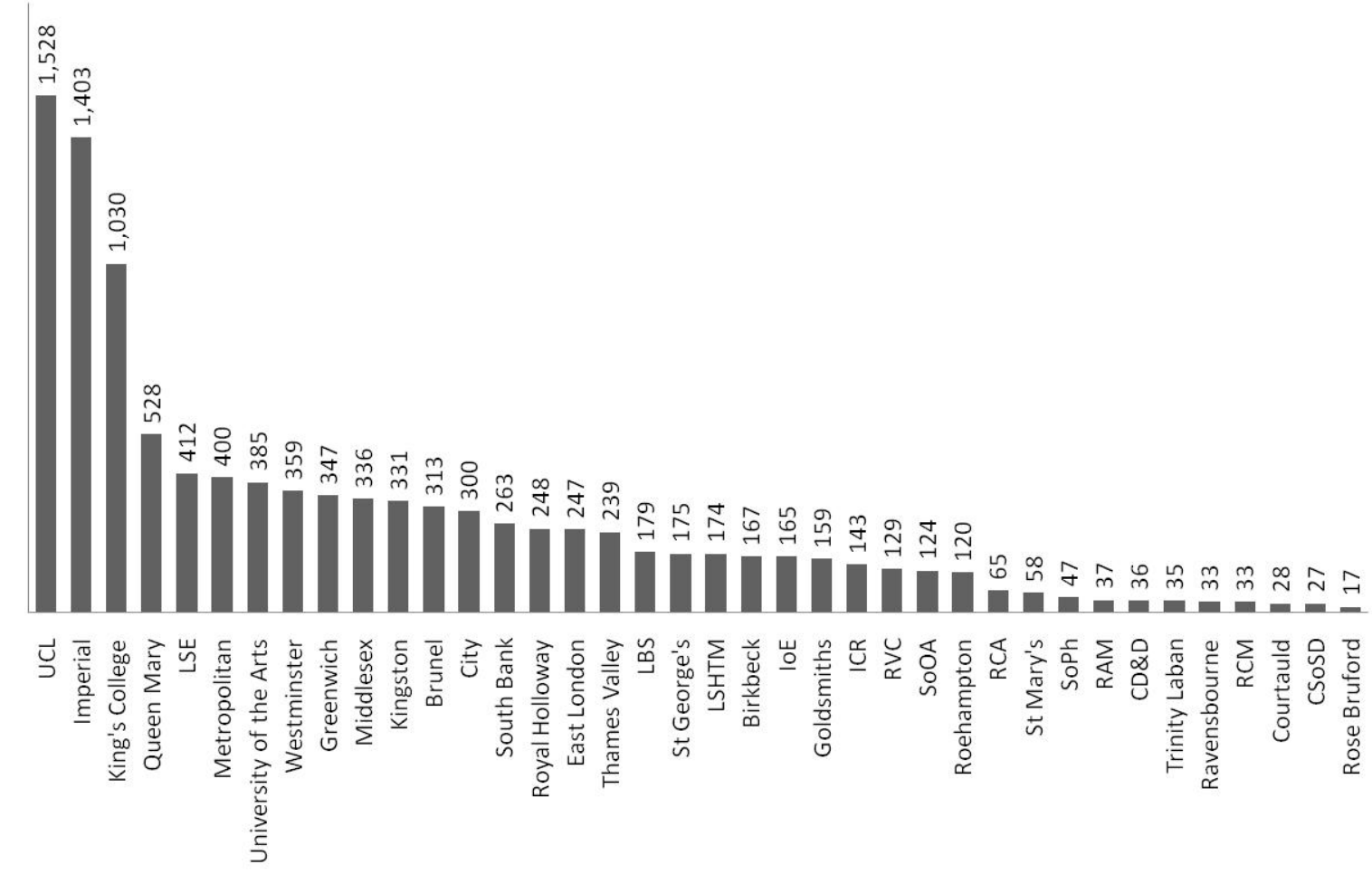

The most striking thing about the multipliers is their comparative uniformity. The lowest conventional Type II output multiplier is 3.03, associated with Roehampton and Thames Valley University, which is $97 \%$ of the highest, 3.13 for the Royal College of Art. The results appear to suggest that London HEIs are rather homogeneous in terms of the intensity of the impact of their expenditures on the English economy. In essence this reflects the similarity of the cost structure of different London institutions, which was indicated in Table 1 by the similarity of the share of wages in total income across London institutions. 
Figure 2 Conventional Type-II output multipliers for London HEIs

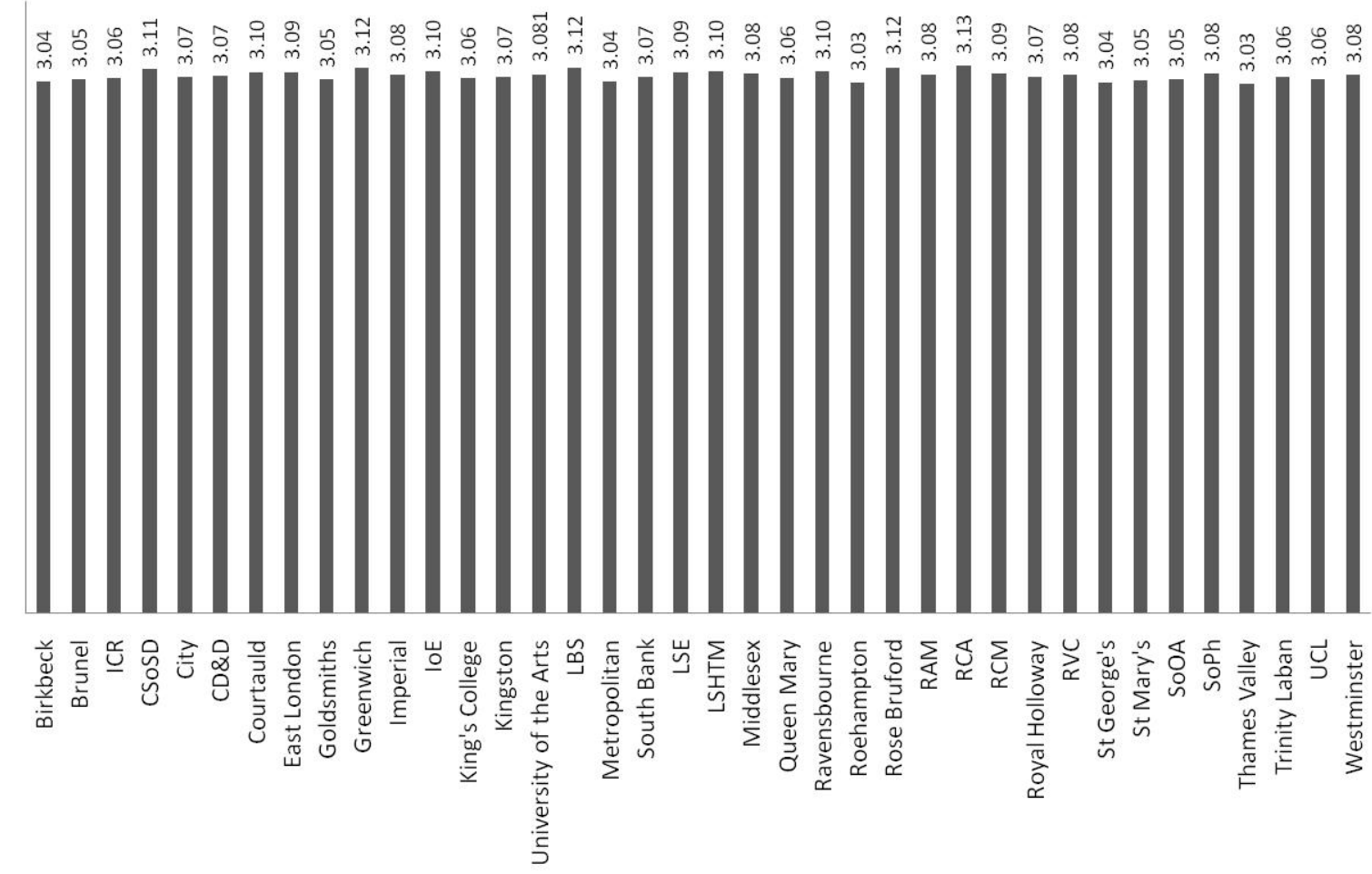

\section{The alternative uses of public funds}

We show in Hermannsson et al (2010b), that allowance for alternative uses of public funding of London HEIs has an important impact on estimates of the expenditure effects of the HEI sector as a whole. The issue is that in so far as the government expenditure on HEIs displaces other public expenditure in England, this is important for assessing regional impacts. Here we extend this analysis to individual institutions and show that the effect of public funding varies significantly among London HEIs.

We divide the direct expenditure on the output of each London HEI into government funding $\left(\mathrm{bf}_{i}\right.$ ) (reflecting the fact that for devolved regions these come through the operation of the Barnett formula), which comes mostly 
through HEFCE, and other funding $\left(\mathrm{of}_{i}\right)$ which includes all other sources of funds such as exports to the rest of the UK and the rest of the World. The conventional attribution to an individual HEI is simply:

$$
q_{i}=\left(b f_{i}+o f_{i}\right) m_{i}
$$

where $\mathrm{bf}_{i}+o f_{i}=\mathrm{f}_{\mathrm{i}}$. For Type-II output attribution, these are the values reported in column 2 of Table 2 and plotted in Figure 1.

The adjusted, or "balanced expenditure", attribution subtracts the publicly funded element of each HEI's funds and the associated own-multiplier effects. This is calculated as $b_{f} m^{p}$, where $\mathrm{m}^{p}$ is the Type-II multiplier for the aggregated public sector (and so is invariant across HEIs). ${ }^{8}$ The balanced expenditure attribution, $\mathrm{q}_{\mathrm{i}}^{\mathrm{B}}$ is therefore given by equation 4 .

$$
q_{i}^{B}=\left(b f_{i}+o f_{i}\right) m_{i}-b f_{i} m^{P}=o f_{i} m_{i}+b f_{i}\left(m_{i}-m^{P}\right)
$$

To summarise, the output impact of an individual HEI net of its government funding equals the sum of the output impact attributable to other funding sources $o f_{i} m_{i}$ and the impact of switching from general public expenditure to HEIs, $b f_{i}\left(m_{i}-m^{p}\right)$. This latter term is positive if the individual HEI multiplier, $\mathrm{m}_{i}$, is greater than the aggregate public sector multiplier, $\mathrm{m}^{\mathrm{p}}$, and negative if it

\footnotetext{
${ }^{8} \mathrm{~m}^{\mathrm{P}}$ is the weighted sum of the sectoral multiplier values, where the weights are the shares of total public sector expenditure in that sector. Therefore $\mathrm{m}^{\mathrm{p}}=\sum \alpha^{\mathrm{p}}{ }_{\mathrm{i}} \mathrm{m}_{\mathrm{i}}$ where $\alpha^{\mathrm{p}}{ }_{\mathrm{i}}=\mathrm{f}_{\mathrm{i}}^{\mathrm{p}} / \sum \mathrm{f}^{\mathrm{p}}{ }_{\mathrm{i}}$.
} 
is not. Dividing equation (3) through by total final demand for the ith HEI, $\mathrm{bf}_{i}+\mathrm{of}_{i}$, yields a "balanced expenditure" multiplier, $\mathrm{m}^{\mathrm{B}}{ }_{\mathrm{i}}$, given by:

$$
m_{i}^{B}=\left(1-\alpha_{i}\right) m_{i}+\alpha_{i}\left(m_{i}-m^{P}\right)=m_{i}-\alpha_{i} m^{P}
$$

where $\alpha_{i}$ is the share of government expenditure in HEI i's total final demand.

The balanced expenditure multiplier shows the impact of a $£ 1$ increase in final demand (with a constant composition) for HEI i. This multiplier value takes into account the fact that a portion of final demand will be switched from general public expenditure ${ }^{9}$. The balanced expenditure multipliers for all London HEIs are shown in Figure 3, together with their conventional IO counterparts. All of the balanced expenditure Type-II multipliers are positive but lower than their corresponding conventional values. All London HEIs receive significant levels of government funding, and netting out the impact of this funding inevitably reduces the measured impact of HEIs' expenditures.

A key feature of the results is that there is considerable variation in the balanced expenditure multipliers across HEIs in London. The minimum value of the multiplier is 0.28 for St Mary's, less than $10 \%$ of the value of its

\footnotetext{
${ }^{9}$ The balanced expenditure multiplier is a weighted average of the individual HEI's multiplier and the switching multiplier ( $\mathrm{mi}-\mathrm{mp}$ ). The weights are the proportions of government and other funding in the HEI's total final demand. The intuition is clear: switching public expenditure to the HEI has no effect on the impact attributed to the HEI's other funding sources, which continue to exert the expected impact (mi), weighted by the share of other funds (1- $\alpha \mathrm{i})$. The public expenditure that is switched has a multiplier value whose sign and scale is determined by the difference between the HEI's own multiplier and the aggregate public sector multiplier ( $\mathrm{mi}-\mathrm{mp}$ ), and this is weighted by the share of public expenditure in total final demand for this HEI's output, $\alpha$ i.
} 
corresponding Type II multiplier (3.05), and the maximum value is 2.60 for LBS, $83 \%$ of its conventional multiplier (3.12). The mean value of the balanced expenditure multipliers for London HEIs is 1.21 , which is $39 \%$ of the mean of their Type II multipliers (3.07). Recall that, for conventional Type II multipliers, the smallest value was $97 \%$ of the largest among the London HEIs: for the balanced budget multipliers the comparable figure is $11 \%$. The range of multiplier values has increased significantly relative to the conventional IO multipliers.

\section{Figure 3 Balanced expenditure multipliers for London HEIs}

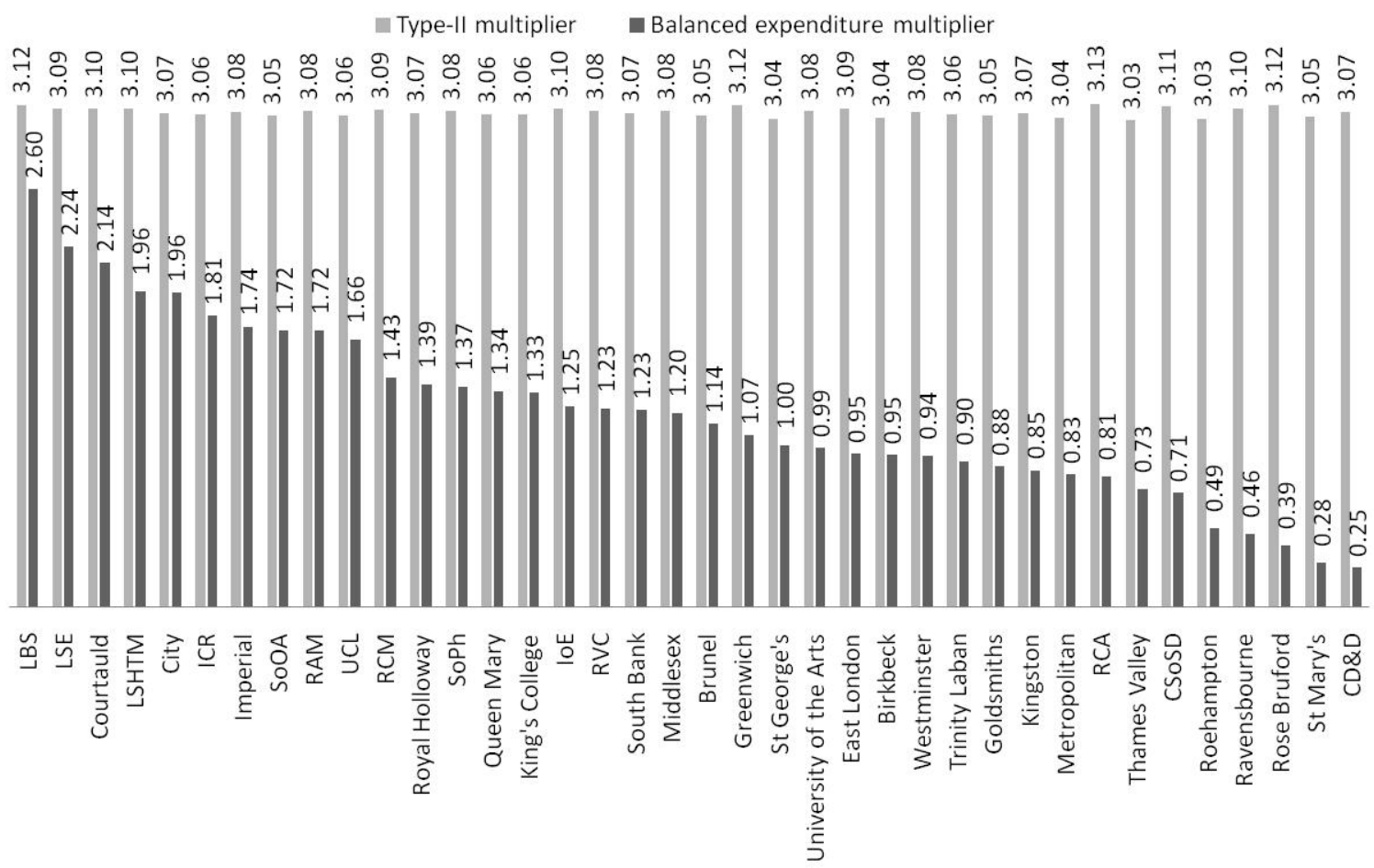

It is apparent from equation (4) that the proportion of HEIs' funding coming from the public sector is going to have a major impact on an HEI's balanced expenditure multiplier. We already know that there is limited variation in HEIs own expenditure multiplier $\left(\mathrm{m}_{i}\right)$ and the aggregate public expenditure multiplier 
$\left(\mathrm{m}^{\mathrm{p}}\right)$ is invariant across HEIs, so the main source of variation is in the size of the term $-\alpha_{i} m^{p}$ which is directly related to the share of government funding in total final demand for the HEI $\left(\alpha_{i}\right)$. On average London HEIs' balanced expenditure multipliers are around $48 \%$ of their Type II multipliers.

\section{The overall impact of HEIs' and their students' expenditures}

Conventional IO impact analyses of student expenditures typically adopt one of two quite different approaches. They either treat all HEI students' expenditures as additional expenditure within the host region (Harris, 1997) or only consider the expenditures of students who move into the region to study as additional (Kelly et al, 2004). Our view is that these alternative perspectives are effectively approximations to, and special cases of, an IO accounting approach in which the key distinction is between those expenditures (or parts of expenditures) that are exogenous and those that are endogenous. Hermannsson et al (2013ab) implement this approach for Scotland using the survey by Warhurst et al (2009), combined with the database employed in our preceding analysis. Here we implement the approach using a survey of the expenditures of students attending English HEIs by Johnson et al (2009) ${ }^{10}$. By analogy with the discussion in Section 4 above, we can distinguish between the government funding of students and other student funding and engage in a similar attribution analysis that identifies balanced expenditure multipliers for students’ expenditures.

\footnotetext{
${ }^{10}$ For details see appendix in Hermannsson et al (2010b).
} 
Here we wish to provide an overall analysis of HEI impacts by adding student expenditure impacts to those of the HEIs' own expenditures as discussed in Sections 3 and 4 . This implies that for each $£ 1$ million of HEI final demand expenditure we calculate the associated student numbers and the impact on the local economy that occurs from those students' exogenous consumption. ${ }^{11}$ The exogenous expenditure per student does vary between students of different types. To accommodate this we use an equation of the following form:

$$
m_{i}^{S}=\frac{m^{C} S_{i}}{f_{i}} \sum_{n} \gamma_{i, n} c_{n} x_{n}
$$

where $\mathrm{m}^{\mathrm{S}}{ }_{\mathrm{i}}$ is the student consumption multiplier, $\mathrm{m}^{\mathrm{C}}$ is the standard consumption multiplier, $s_{i}$ is the number of students in HEI $i$ and there are $n$ student types. $\gamma_{i, n}$ is the proportion of the students in HEI $i$ in type $n, c_{n}$ is the average consumption from student group $\mathrm{n}$ and $\mathrm{x}_{\mathrm{n}}$ is the proportion of the income of group $\mathrm{n}$ that is exogenous. In the present application we have three groups: English students, students from the rest of the UK and students from the rest of the world.

Figure 4 gives the conventional Type II student consumption multiplier value where the associated output is expressed as a proportion of HEI expenditure. These are conventional multiplier values in that they do not include any adjustment for public sector expenditure switching. For each HEI, this figure has been added to the conventional Type II HEI output multiplier value shown

\footnotetext{
${ }^{11}$ In order to determine exogenous consumption we subtract student consumption financed from wages and intra-family transfers. Also, where appropriate, we adjust for maintenance grants.
} 
in Figure 2. Note that the associated student consumption multipliers vary widely across HEIs, from 1.56 for Middlesex $(46.3 \%$ of the institutional expenditure multiplier), to 0.03 for Institute of Cancer Research, clearly an outlier, reflecting its highly specialist focus and functions.

Figure 4 Aggregate multipliers of London HEIs (MAi) the darker area shows the institutional component (the standard IO multiplier Mi) while the lighter shaded area shows the student consumption component (MSi)

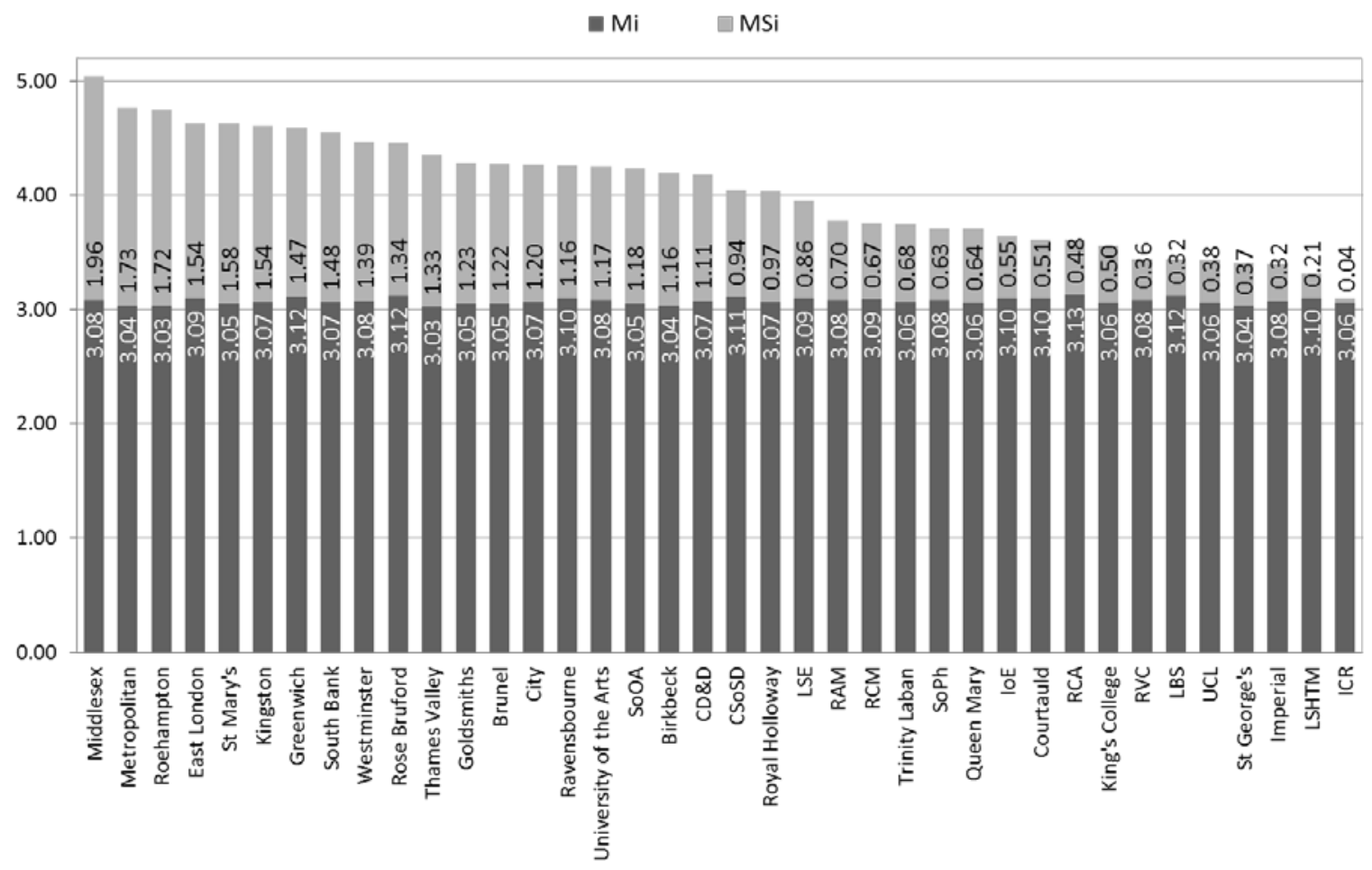

Figure 5 shows the total balanced expenditure multiplier values for each London HEI. That is to say, the student multiplier value is also adjusted to take into account reduced public expenditure elsewhere in England as a result of maintenance grants from the government. This multiplier is then added to the HEI balanced expenditure values given in Figure 3. 
Figure 5 Aggregate balanced expenditure multipliers of London HEIs (MABi). [The darker area shows the institutional component (MBi) while the lighter shaded area shows the student consumption component (MBSi).]

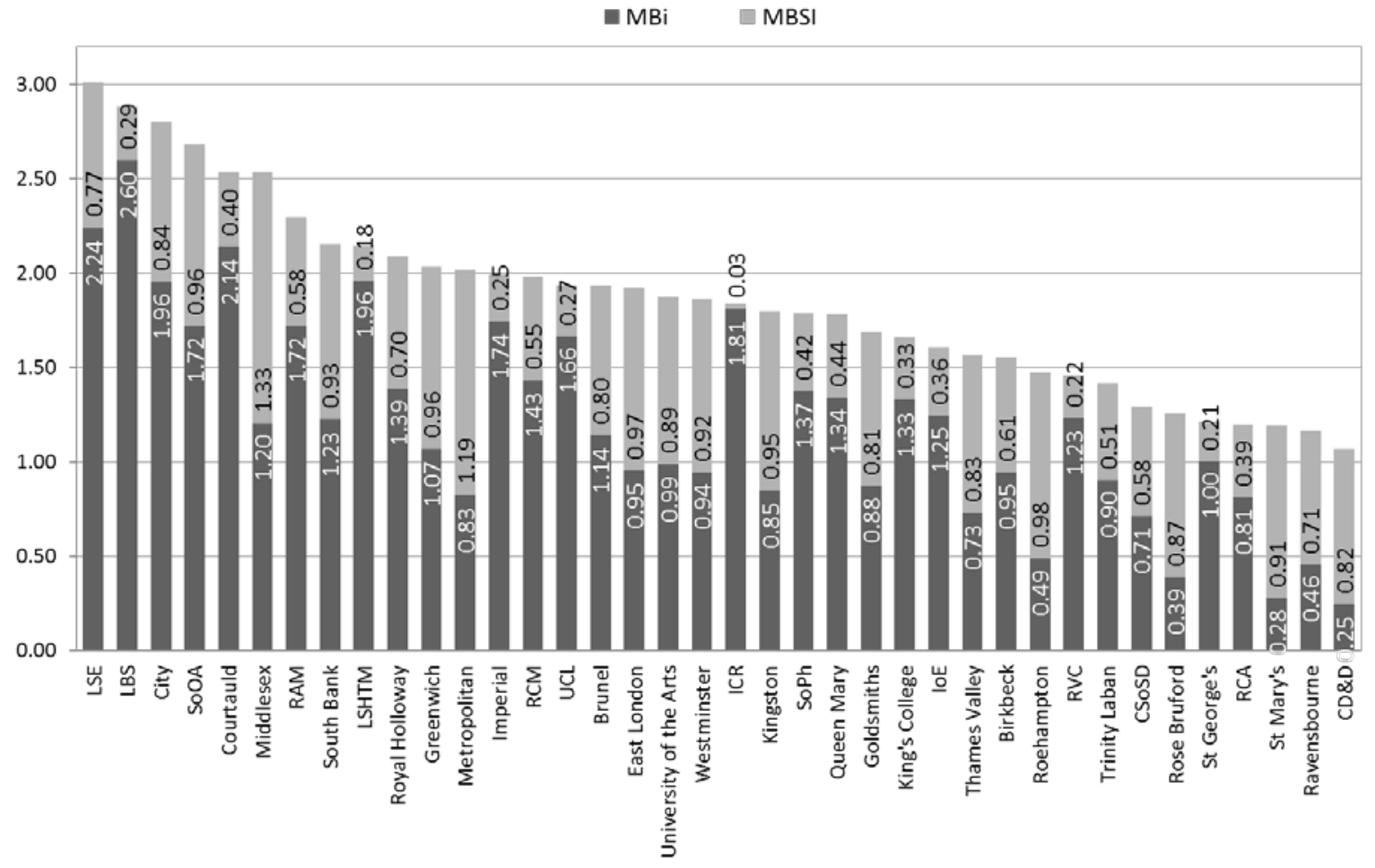

Taking into account public sector expenditure switching implies a downward adjustment to the student consumption multiplier. However this downward adjustment is in general small relative to the adjustment to the HEI expenditure multiplier. This has several implications. First, for some institutions, student consumption makes up a large share of their total balanced expenditure multiplier. So for Metropolitan, the student expenditure accounts for $51 \%$ of the total impact, but for London School of Hygiene and Tropical Medicine it accounts for only $8.4 \%$. Second, the combined impact of HEI and student expenditure means that for all institutions the multiplier value is greater than 
unity. Indeed for LSE it is in excess of 3.0 and a further 11 HEIs have a multiplier in excess of 2.0. Third, the addition of student spending leads to a marked change in the ordering of HEI's by their balanced budget multiplier values. Finally, the multiplier values reflect the wide range of activities undertaken by different HEIs. For example, Imperial and Metropolitan have similar balanced expenditure multiplier values but their decomposition into university and student expenditure effects are quite different.

\section{Conclusions}

In this paper we explore the expenditure impacts of London HEIs and their students on the economy of England by applying an IO attribution analysis to a purpose-built, HEI-disaggregated English IO table. Using a conventional IO analysis the level of HEIs' own expenditure impacts on GDP vary considerably from the $£ 1,528$ million contributed by UCL to the $£ 17$ million impact of Rose Bruford. However, when expenditure effects are corrected for scale and expressed in terms of conventional multipliers, HEI impacts appear comparatively invariant across HEIs in London.

Given the "policy scepticism" argument that public funds allocated to HEIs could in principle be diverted to other uses, which would also drive knock-on impacts, does that imply that HEI expenditure impacts are in effect negligible or even zero? We investigate this hypothesis by conducting simulations in which we subtract from the overall HEI impact the effect that its public funding would have if it was used instead to expand the public sector. The resultant 
balanced expenditure multipliers are all positive, but are considerably smaller than conventional IO impacts. The balanced expenditure multipliers also exhibit considerable heterogeneity, reflecting to a large degree the different extents to which individual HEIs obtain their funding from the government (via HEFCE).

We adopt a new method of attributing impacts to the expenditure of HEIs' students, a method which accommodates earlier treatments as special cases. These impacts vary very substantially across HEIs, reflecting the student intensity of the institution and the geographical source of the student body. Incorporation of these effects within aggregate (institutional and student) conventional IO and balanced expenditure multipliers, tends to reduce slightly the degree of heterogeneity among HEIs in terms of aggregate expenditure impacts at least (and has the impact of improving the estimated impacts of the post 1992 universities).

This makes clear that it is not only the overall level of income that matters for determining the expenditure impact of London HEIs but also the composition of the income by source. This is because of the public budget constraint. Broadly speaking, the less dependent the institution is on grants from the funding council, the larger the multiplier of its own expenditures. Superficially, this would suggest that teaching centred institutions focussing on a local catchment area should have a low multiplier, whereas prestigious research based institutions able to draw in research funding and large tuition fees should exhibit a large multiplier. This is partially accurate, as manifested in the results for the institutional multipliers. However, this ignores the role of students' 
consumption expenditures, which drive a significant impact on top of the institution's own expenditures. The magnitude of this multiplier is driven by both the student intensity of the institution as well as the composition of the student body. Accounting for this significantly modifies the overall impact with the result that a priori it is not possible to generalise that a particular type of HEI will exhibit a higher overall multiplier than another type.

Overall, our analysis implies a more complex and subtle view of the expenditure impacts of HEIs than is traditionally associated with impact studies of the sector. Crude IO estimates of impact suggest a homogeneity that we think is misleading. It is important to note that our analysis rejects the "policy scepticism” perspective, at least in its limiting form: HEI expenditure impacts are important, but their measurement should acknowledge the possible alternative uses of public expenditure within the host region.

We end on a cautionary note: this study is concerned exclusively with the expenditure, or demand-side, impacts of HEIs. These are not the only, and are probably not the most important, impacts that HEIs have on their host economies. For example, one key contribution that HEIs can make to their host regions, at least in principle, is their supply of skilled graduates whose (private) benefits are apparent through graduate wage premia. In our analysis of expenditure impacts, in-coming students' expenditures typically have the biggest impact. However, these might be the very students who are least likely to stay and stimulate the host region in the longer term, through their enhanced productivity. 


\section{References}

Acs, Z. J. (2009). Jaffe-Feldman-Varga: the search for knowledge spillovers. In Varga, A. (ed) Universities, Knowledge Transfer and Regional Development. Cheltenham: Edward Elgar.

Andersson, R., Quigley, J.M. \& Wilhelmsson, M. (2009). Urbanization, Productivity, and Innovation: Evidence from Investment in Higher Education. Journal of Urban Economics. Vol. 66, pp. 2-15.

Anselin, L., Varga, A. \& Acs, Z. (1997). Local Geographic Spillovers between University Research and High Technology Innovations. Journal of Urban Economics. Vol. 42. pp. 422-448.

Anselin, L., Varga, A. \& Acs, Z. (2000). Geographic and Sectoral Characteristics of Academic Knowledge Externalities. Papers in Regional Science. Vol. 79, No. 4, pp. 435-443.

Armstrong, H.W. (1993), "The Local Income and Employment Impact of Lancaster University”

Armstrong, H. \& Taylor, J. (2000), Regional Economics and Policy, 3rd edition., Oxford: Blackwell Publishers. 
Battu, H., Finch, J.H. \& Newlands, D. (1998), “Integrating Knowledge Effects into University Impact Studies: A Case Study of Aberdeen University”,. Department of Economics, University of Aberdeen.

Blake, C. \& McDowell, S. (1967) A Local Input Output Table. Scottish Journal of Political Economy. Vol. 14, pp. 227-242.

Bleaney, M.F., Binks, M.R., Greenaway, D., Reed, G.V. \& Whynes, D.K. (1992), What Does a University Add to Its Local Economy, Applied Economics, vol. 24, pp. 305-311.

Blundell, R., Deardren, L. \& Sianesi, B. (2005). Measuring the Returns to Education, in Machin, S. \& Vignoles, A. (eds) What's the Good of Education: The Economics of Education in the UK. Princeton \& Oxford: Princeton University Press.

Bradley, S. and Taylor, J. (1996). Human Capital Formation and Local Economic

Performance. Regional Studies, Vol.. 30, No. 1, pp. 1-14.

Brownrigg, M. (1973), “The Economic Impact of a New University”, Scottish Journal of Political Economy, vol. 10, no. 2, pp. 123-139.

Checchi, D. (2006). The Economics of Education: Human Capital, Family Background and Inequality. Cambridge: Cambridge University Press. 
Drucker, J., \& Goldstein, H. (2007). Assessing the regional economic development impacts of universities: a review of current approaches. International regional science review, Vol. 30, No. 1, pp. 20-46.

Faggian, A., McCann, P. \& Sheppard, S. (2010). Higher Education, Graduate Migration and Regional Dynamism in Great Britain. In Varga, A. (ed.). Universities, Knowledge Transfer and Regional Development: Geography, Enterpreneurship and Policy. Cheltenham: Edvard Elgar.

Fischer, M. \& Varga, A. (2003). Spatial knowledge spillovers and university research: Evidence from Austria. Annals of Regional Science. Vol. 31, No. 2, pp. 303-322.

Florax, R.J.G.M. (1992), The University: A Regional Booster?, Aldershot: Avebury.

Goldstein, H. A. (2009). What we know and what we don't know about the regional economic impacts of universities. In Varga, A. (ed) Universities, Knowledge Transfer and Regional Development. Cheltenham: Edward Elgar.

Harmon, C. \& Walker, I. (2003). The Returns to Education: Microeconomics. Journal of Economic Surveys, Vol. 17, No. 2, pp. 115-153. 
Harris, R.I.D. (1997), “The Impact of the University of Portsmouth on the Local Economy”, Urban Studies, vol. 34, pp. 605-626.

Hermannsson, K., Lisenkova, K., McGregor, P. \& Swales, K. (2010a). An HEIDisaggregated Input-Output Table for Scotland. Strathclyde Discussion Papers in Economics, 10-14.

Hermannsson, K., Lisenkova, K., McGregor, P. \& Swales, K. (2010b). "Policy Scepticism" and the Impact of London-based Higher Education Institutions (HEIs) on the Economy of England: Accounting for Alternative Uses of Public Expenditure. Strathclyde Discussion Papers in Economics, 10-29

Hermannsson, K., Lisenkova, K., McGregor, P. \& Swales, K. (2013a). Policy Scepticism and the Impact of Scottish Higher Education Institutions (HEIs) on their Host Region: Accounting for Regional Budget Constraints under Devolution. Regional Studies, forthcoming. Pre-published online: http://dx.doi.org/10.1080/00343404.2012.697139

Hermannsson, K., Lisenkova, K., McGregor, P. \& Swales, K. (2013b). The Expenditure Impacts of Individual Higher Education Institutions (HEIs) and their Students on the Scottish Economy under Devolution: Homogeneity of Heterogeneity? Environment and Planning A, Vol. 45, No. 3, pp. $710-727$. 
Hermannsson, K., Lecca, P., Lisenkova, K., McGregor, P. \& Swales, K. (forthcoming). The Importance of Graduates for the Scottish Economy: A “Micro-to-Macro” Analysis. Environment and Planning A, forthcoming.

HESA - Higher Education Statistics Agency (2007). Resources of Higher Education Institutions 2005/06.

Jaffe, A.B. (1989). Real Effects of Academic Research. The American Economic Review. December 1989. Vol. 79. No. 5.

Johnson, C., Pollard, E., Hunt, W., Munro, M., Hillage, J., Parfrement, J. \& Low, N.A. (2009). Student Income and Expenditure Survey 2007/08: Englishdomiciled Students. Report prepared by the Institue for Employment Studies and the National Centre for Social Research for the Department for Innovation, Universities \& Skills Retrieved from the World Wide Web: http://www.bis.gov.uk/assets/biscore/corporate/migratedd/publications/d/dius_r $\underline{\text { r_09_05.pdf }}$

Kelly, U., McNicoll, I. \& McClellan, D. (2004), “The Impact of the University of Strathclyde on the economy of Scotland and the City of Glasgow”, Project Report, University of Strathclyde, Glasgow, United Kingdom.

Loveridge, S. (2004). “A Typology and Assessment of Multi-sector Regional Economic Impact Models”. Regional Studies, Vol. 38, No. 3m pp. 305 - 317 
Lundvall, B.A. (2008). Higher Education, Innovation and Economic Development. In Lin, J.Y. \& Plescovic, B. (eds.) Higher Education and Development: Washington: The World Bank.

McGregor, P., Swales, K. \& Yin, Y.P. (1996), “A long-run interpretation of regional input - output analysis”, Journal of Regional Science, vol. 36, pp. 479501.

McGregor, P., Swales, K \& McLellan, D. (2006), "The Overall Impact of Higher Education Institutions on Regions: A Critical Review”, in Centre for Public Policy for the Regions's “Network on the Overall Impact of HEIs on Regional Economies: Final Report”, Centre for Public Policy for Regions, Glasgow.

McMahon, W.W. (2004). The Social and External Benefits of Education. In Geraint, J. \& Johnes. J. (eds.) International Handbook on the Economics of Education. Cheltenham: Edward Elgar.

McMahon, W.W. (2009). Higher Learning, Greater Good: The Private and Social Benefits of Higher Edudation. Baltimore: The John Hopkins Press.

Miller, R.E. \& Blair, P.D. (2009), “Input-Output Analysis: Foundations and Extensions, second edition“. Cambridge: Cambridge University Press. 
Parker, D.D. \& Zilberman, D. (1993). University Technology Transfers: Impacts On Local And U.S. Economies. Contemporary Economic Policy. Vol. 11, No. 2, pp. 87-99.

Psacharopoulos, G. \& Patrions, H. A. (2004). Human Capital and Rates of Return. In Geraint, J. \& Johnes. J. (eds.) International Handbook on the Economics of Education.Cheltenham: Edward Elgar.

Siegfried, J. J., A. R. Sanderson \& McHenry, P. (2007). The economic impact of colleges and universities. Economics of Education Review, Vol. 26, pp. 546558.

Varga, A. \& Schalk, A. (2004). Knowledge Spillovers, Agglomeration and Macroeconomic Growth: An Empirical Approach. Regional Studies, Vol. 38, No. 8, pp. 977-989.

Warhurst, C., Commander, J., Nickson, D., Symeonides, A. Furlong, A., Findlay, J., Wilson, F. \& Hurrell, S. (2009). Higher and Further Education Students' Income, Expenditure and Debt in Scotland 2007-08. Edinburgh: Scottish Government Social Research. Retrieved from the World Wide Web: http://www.scotland.gov.uk/Publications/2009/06/24115743/02 